\title{
Constitutive expression and anticancer potency of a novel immunotoxin onconase-DV3
}

\author{
MIAONAN SUN ${ }^{1}$, HUICHUN TANG $^{1}$, YAN GAO $^{2}$, XINXUAN DAI $^{1}$, \\ YUE YUAN $^{1}$, CHUNMEI ZHANG ${ }^{1}$ and DEJUN SUN ${ }^{1}$ \\ ${ }^{1}$ Department of Biomedicine, Regeneration Medicine Institute, Jilin University, Changchun, Jilin 130061; \\ ${ }^{2}$ Jilin Zixin Pharmaceutical Co., Ltd., Changchun, Jilin 130041, P.R. China
}

Received August 24, 2015; Accepted October 8, 2015

DOI: $10.3892 /$ or.2016.4570

\begin{abstract}
Onconase is an RNase of the ribonuclease A superfamily that is purified from the Northern leopard frog (Rana pipiens). It targets several types of malignant tumors, digests cytoplasmic transfer RNA (tRNA), and causes tumor cell apoptosis. Onconase has been employed in clinical trials as an antitumor drug, and has revealed its valuable clinical activity in several types of tumors, particularly pleural mesothelioma. However, its inefficiency in targeting tumor cells and its non-specific toxicity in normal tissues have diminished its clinical benefits. Furthermore, cyclization of the N-terminal glutamine residue (Gln), possesses more RNase activity than the structure of Met ahead of Glu in the N-terminal (99:1), which is more difficult for producing onconase by Pichia pastoris. Under the guidance of $\alpha$-mating factor-pre ( $\alpha$-MF-pre) secretion signal, the secretion of the recombinant protein can reach a high level. In the present study, we constructed a constitutive expression vector for onconase$(\mathrm{DV} 3)_{2}$ (Onc-DV3) production in yeast Pichia pastoris with the GAP promoter, in which the Onc-DV3 gene is inserted downstream of the truncated Saccharomyces cerevisiae $\alpha$-mating factor-pre ( $\alpha$-MF-pre) secretion signal. The immunoRNase Onc-DV3 expressed a high level of production and bioactivity and possessed enhanced capability to deliver the Onc molecule to tumor cell monomeric counterparts. Notably, Onc-DV3 showed strong cytotoxicity to highly metastatic tumor cells, weak cytotoxicity to lowly metastatic tumor cells and no toxicity to normal cells. These results demonstrate that the specific toxicity to highly metastatic tumor cells has made
\end{abstract}

Correspondence to: Professor Dejun Sun, Department of Biomedicine, Regeneration Medicine Institute, Jilin University, Changchun, Jilin 130061, P.R. China

E-mail: sundjj1@126.com

Abbreviations: tRNA, transfer RNA; Onc, onconase; Pre, pre sequence of $\alpha$-mating factor; Onc-DV3, onconase-(DV3) $)_{2}$ MW, molecular weight; Gln, glutamine residue; CXCR4, CXC chemokine receptor 4; CPPs, cell-penetrating peptides; GAP, glyceraldehyde-3-phosphate dehydrogenase; RNase A, ribonuclease A

Key words: onconase, immunotoxin, DV3, metastatic, tumor
Onc-DV3 a promising antitumor drug by using two copies of DV3 for the targeted delivery of onconase.

\section{Introduction}

Onconase (P-30 protein), which is purified from embryos of the Northern leopard frog (Rana pipiens), is a member of the bovine pancreatic ribonuclease A (RNase A) superfamily $(1,2)$. It has a molecular weight of $12.0 \mathrm{kDa}$ and is composed of 104 amino acid (aa) residues (3). Although it is similar in molecular structure to RNase A, it has two unique features: the presence of a Cys87-Cys104 disulphide bond at the C-terminus; and presence of the $\mathrm{N}$-terminal pyroglutamic acid residue, which results from cyclization of the glutamine residue (Gln) in the N-terminal and is an integral part of the active site. Recombinant onconase, which has an N-terminal methionine, has only $1 \%$ activity compared to the native protein. In addition, it has three disulfide bonds that stabilize the protein structure and play a significant role in the resistance to hydrolysis by proteases and heat $(4,5)$.

Onconase has cytotoxicity towards various malignant tumors such as breast, pancreatic, and non-small cell lung cancers, as well as malignant mesothelioma (6-9). Recombinant onconase was the first ribonuclease to be evaluated as a therapeutic drug in humans, and has progressed to phase III clinical trials in patients with unresectable mesothelioma. In vivo and in vitro experiments have shown that onconase has a synergistic effect with many other drugs including chemicals, synthetic drugs, and cytokines (10-13). Many cell surface receptors are overexpressed in multiple tumor types including the HER2 receptor, luteinizing hormone-releasing hormone receptor, and CXC chemokine receptor 4 (CXCR4) $(14,15)$. CXCR4 is overexpressed in more than 23 types of cancer, including melanoma, glioma, acute myelogenous leukemia, chronic lymphocytic leukemia, and breast, prostate, renal, pancreatic, ovarian, cervical, colon, and small-cell lung cancers $(16,17)$. DV3 is the binding sequence of the CXCR4 ligand, thus it has the potential to be used as a target to discern cancer cells in drug design.

Cell-penetrating peptides (CPPs) penetrate the cell membrane barrier and deliver various biological molecule cargoes into the cytoplasm without receptors, including proteins, DNA, RNA, and even nanoparticles (18-20). As 
a typical CPP with the amino acid sequence PFVYLI, PFV delivers fluorescent probes, RNA, and apoptotic peptides into a multiple of cancer cells (21-23).

The methylotrophic yeast Pichia pastoris has developed into a highly successful expression system for the production of a variety of heterologous proteins using its strong and tightly regulated AOX1 promoter $(24,25)$. This AOX1 promoter-controlled expression system depends on the generation of biomass in medium without the use of methanol (25). Despite the remarkable achievements made with this expression system, the use of methanol as the only carbon source can result in a series of issues, such as the consumption of large amounts of dissolved oxygen, the need for pure oxygen to maintain industrial production, and the proteolysis of recombinant proteins during high density fermentation. Furthermore, because methanol is an inflammable, explosive, and toxic substance, it can be dangerous to use (26).

The glyceraldehyde-3-phosphate dehydrogenase (GAP) promoter can be used for the constitutive expression of recombinant heterologous proteins in $P$. pastoris cells using glucose, glycerol, and methanol as carbon sources. Since the GAP promoter-derived expression system allows for continuous production of the recombinant product while avoiding methanol fed-batch fermentation by $P$. pastoris, this system was proposed to be more suitable for large-scale fermentation and production of exogenous recombinant proteins $(27,28)$. The most used and best studied secretion leader in yeast is the $\alpha$-mating factor ( $\alpha$-MF) pre-pro-leader originating from $S$. cerevisiae, which has been used for production of secretory proteins with and without EAEA (Glu-Ala) $)_{2}$ overhang in various yeast species. Of the three types of leading sequences that can be used [pre sequence (19 aa), pre+pro sequence, pre+pro+EAEA], only the pre sequence resulted in high onconase bioactivity.

\section{Materials and methods}

Materials. All restriction enzymes were purchased from New England Biolabs (Beverly, MA, USA) and DNA polymerase was obtained from Takara (Dalian, Liaoning, China). Yeast extracts and peptone were purchased from Oxoid (Basingstoke, UK). Luria Bertani (LB) medium and yeast extract peptone glucose (YPD) components were purchased from Beijing Chemical Industry (Beijing, China). Escherichia coli TOP10 cells were used for plasmid maintenance. Zeocin, $P$. pastoris $\mathrm{X} 33$, and pGAPzaA were purchased from Invitrogen (Carlsbad, CA, USA) and used for the expression process.

Growth media and conditions. YPD broth (1\% yeast extract, $2 \%$ peptone, and 2\% glucose) containing Zeocin (100, 200, 300 , and $400 \mu \mathrm{g} / \mathrm{ml}$ ) was employed for selection of $P$. pastoris transformants at $30^{\circ} \mathrm{C}$. Low salt LB $(1 \%$ tryptone, $0.5 \%$ yeast extract, and $0.5 \% \mathrm{NaCl}, \mathrm{pH} 7.0)$ with Zeocin $(25 \mu \mathrm{g} / \mathrm{ml})$ were employed to culture E. coli TOP10 transformants at $37^{\circ} \mathrm{C}$.

Plasmid and strains. A 560-base pair (bp) Pre-Onc-DV3 fusion gene fragment was synthesized by GenScript Corporation (Nanjing, China) after optimization. Both pGAPzaA and the Pre-Onc-DV3 gene were double digested by BstBI and $E c o$ RI, and the digested gene was inserted into the open reading frame under control of the GAP promoter, resulting in the pGAPZ $\alpha$ A-Pre-onconase-PFV-DV3 expression vector (Fig. 1). The recombinant plasmid was transferred into E. coli Top10 cells, and screened on low salt LB containing $25 \mu \mathrm{g} / \mathrm{ml}$ Zeocin. The extracted recombinant plasmid was identified by digesting with $B g l \mathrm{II}$ and $E c o$ RI, linearized with $B \ln \mathrm{I}$, and transformed into $P$. pastoris X33 cells by electroporation. The electrocompetent $P$. pastoris X33 cells were prepared according to standard methods, and using an electroporator (Scientz, Ningbo, China) following the manufacturer's instructions. The electroporation conditions were $1.5 \mathrm{kV}, 25 \mu \mathrm{F}$, and $200 \Omega$.

Screening of clones. The transformed X33 clones were screened on YPD agar plates containing $100 \mu \mathrm{g} / \mathrm{ml}$ zeocin for 3 days. The chosen transformants were screened for Zeocin-level clones from the YPD agar plates containing a higher Zeocin concentration $(200,300$, and $400 \mu \mathrm{g} / \mathrm{ml})$. All of these high-level secretion clones were confirmed by PCR using X33 transformant DNA, and selected according to the Onc-DV3 recombinant protein concentration on SDS-PAGE. The promising X33 transformants were grown in $10 \mathrm{ml}$ YPD medium in a 100-ml flask for $24 \mathrm{~h}$. Then, the culture was transferred to $100 \mathrm{ml}$ YPD medium for $24 \mathrm{~h}$ in a 1,000-ml flask. The inoculums were cultivated to $\mathrm{OD}_{600}$ of 0.5 as starting seed cells to investigate the effects of culture parameters: i) carbon source cells were cultured in $2 \%$ (w/v) of different carbon sources (glucose, glycerol, methanol, sucrose, sorbitol); ii) nitrogen source cells were cultured in $2 \%$ $(\mathrm{w} / \mathrm{v})$ of different nitrogen sources [tryptone, peptone, yeast extract, beef extract, $\left(\mathrm{NH}_{4}\right)_{2} \mathrm{SO}_{4}$; ; iii) the cells were cultured under different temperatures $\left(21,24,27,30\right.$, and $\left.33^{\circ} \mathrm{C}\right)$; and (iv) the cells were cultured under a different $\mathrm{pH}(4.5,5.0,5.5$, $6.0,6.5,7.0,7.5,8.0)$.

The concentration of the Onc-DV3 recombinant protein was determined by SDS-PAGE and RNA hydrolytic activity. All of the data are expressed as the mean \pm standard deviation (SD) of independent triplicate determinations.

Western blot analysis. Western blot analysis was performed to determine the concentration of Onc-DV3. Briefly, samples were collected at various time-points $(35,45,55,65$, and $75 \mathrm{~h})$, and resolved by SDS-PAGE. Then, the proteins were electrophoretically transferred to polyvinylidene fluoride (PVDF) membranes (Millipore Co., Ltd., Boston, MA, USA) using a DYCZ-40G transfer blotter (Beijing Liuyi Co., Ltd., Beijing, China). The membranes were incubated in blocking buffer (10 mM Tris- $\mathrm{HCl}, 150 \mathrm{mM} \mathrm{NaCl}, 5 \%$ skim milk, $\mathrm{pH} 7.5$ ) at room temperature for $2 \mathrm{~h}$, after which they were incubated with a polyclonal antibody of DV3 at room temperature for $4 \mathrm{~h}$. Next, the membranes were washed three times with TBS containing $0.05 \%$ Tween-20, and incubated with goat anti-rabbit $\mathrm{IgG}$ peroxidase conjugate (diluted 1:100; Boster Co., Ltd., Wuhan, Hubei, China) at room temperature for $4 \mathrm{~h}$. The membrane was incubated with a substrate solution containing $0.06 \%$ (w/v) chloronaphthol and $0.01 \% \mathrm{H}_{2} \mathrm{O}_{2}$ (both from Beijing Chemicals) after washing.

Fed-batch fermentation. A 50-1 fermentor was applied to evaluate the ability for larger scale constitutive expression of Onc-DV3 immunotoxin using the GAP promoter in 


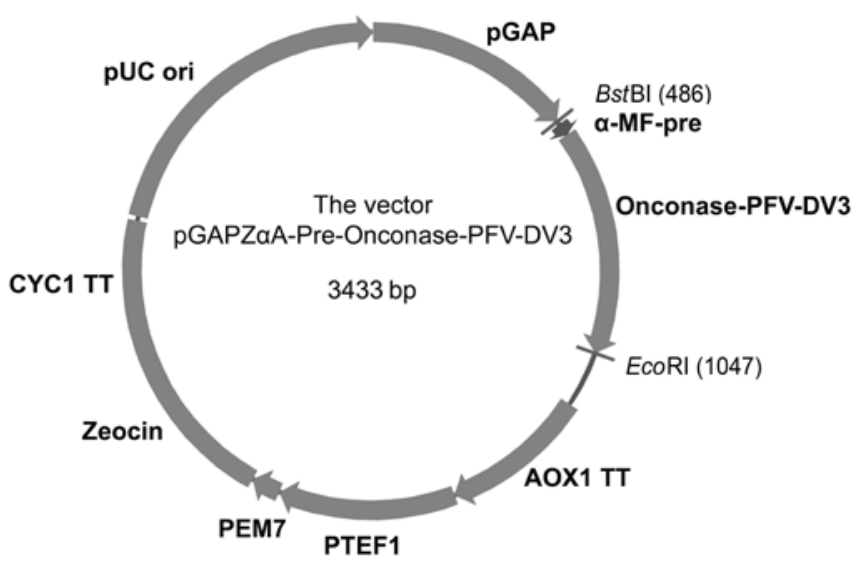

Figure 1. Map of the constitutive expression vector pGAPZ $\alpha$ A-Pre-Onc-DV3. The Pre-Onc-DV3 gene was inserted into pGAPZ $\alpha$ A using BstBI and EcoRI sites.

P. pastoris, with the aforementioned method. The time-course for biomass and production of Onc-DV3 in the 50-1 fermentor was determined. The production value of the recombinant immunotoxin increased with biomass until $72 \mathrm{~h}$. The biomass $\left(\mathrm{OD}_{600}\right)$ was elevated to $\sim 300$ during fed-batch fermentation in a 50-1 fermentor. The production of Onc-DV3 in the 50-1 fermentor reached about $2 \times 10^{6} \mathrm{U} / 1$ after $72 \mathrm{~h}$ of fermentation, compared to $6 \times 10^{5} \mathrm{U} / 1$ in a shake flask.

Biomass analysis, protein concentration determination, and cell viability assay. Biomass in the culture broth was determined by cell density expressed as optical absorbance $\left(\mathrm{OD}_{600}\right)$. The protein concentration was determined using the Bradford assay kit (Sangon, Shanghai). Cell growth was monitored using a model UV-4802H spectrophotometer (Unico, Shanghai, China) at a wavelength of $490 \mathrm{~nm}$, and converted to dry cell weight using a predetermined correlation factor.

Purification of onconase-DV3 fusion protein. The culture broth was collected after $72 \mathrm{~h}$, and yeast cells were removed by centrifugation at $8,000 \mathrm{rpm}$ for $30 \mathrm{~min}$ at $4{ }^{\circ} \mathrm{C}$. The centrifuged liquid was ultrafiltrated and concentrated by ultrafiltration using the Amfore ultrafiltration membrane 10000. The concentrated recombinant immunotoxin was loaded onto a SP Sepharose Fast Flow column $(5.0 \times 20 \mathrm{~cm})$ that was pre-equilibrated with buffer A (20 mM PB, pH 7.0). The bound recombinant immunotoxin was eluted with buffer $\mathrm{B}(1 \mathrm{~mol} / 1 \mathrm{NaCl})$. The eluted protein was mixed with buffer $\mathrm{C}(20 \mathrm{mM} \mathrm{PB}, \mathrm{pH} 7.0)$ and further loaded onto the Sephadex G-75 column $(1.6 \times 100 \mathrm{~cm})$ that was pre-equilibrated with the same buffer. The purity of the recombinant immunotoxin from the final eluate was analyzed by SDS-PAGE.

Determination of the biological activity of the onconase. In order to determine the RNA degradation activity of onconase in vitro, $10 \mu \mathrm{g}$ Pichia RNA was added in a $100-\mu 1$ reaction

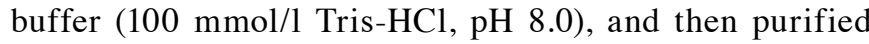
onconase solutions at different concentrations $(100,10,1$, and $0.1 \mu \mathrm{g} / \mathrm{ml}$ ) were added. The tubes were incubated in a water bath at $37^{\circ} \mathrm{C}$ for $30 \mathrm{~min}$. The control group was incubated under the same conditions, but standard RNase A was added

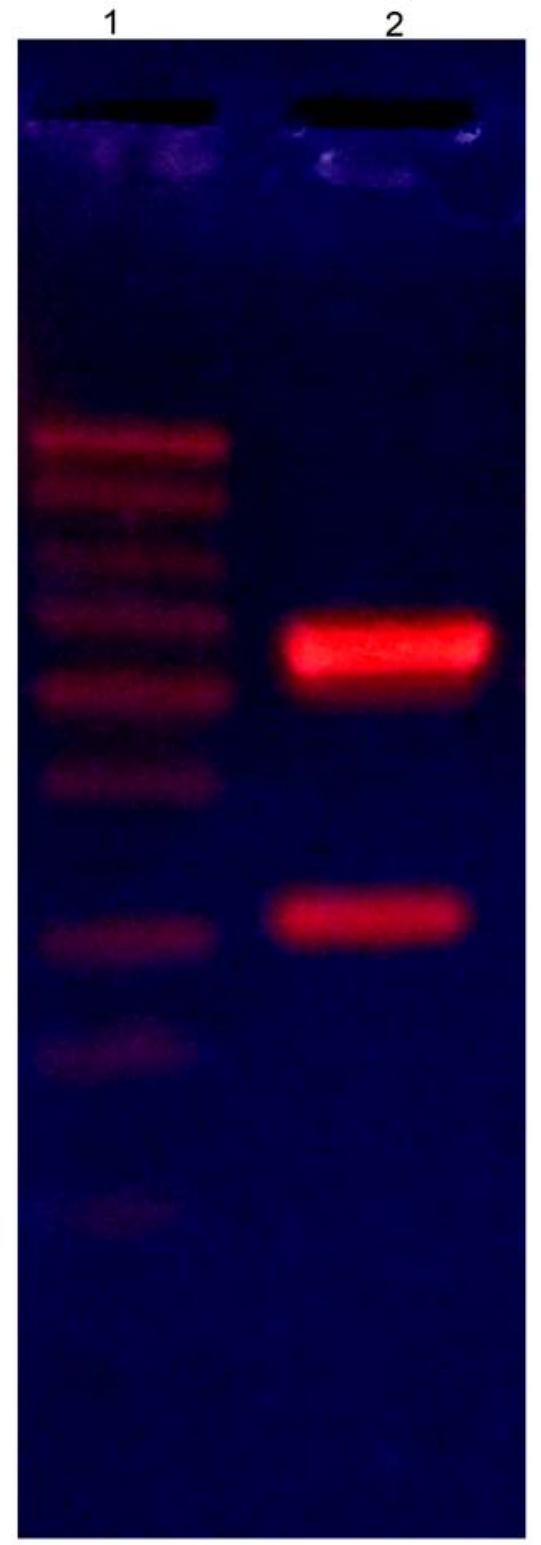

Figure 2. The constitutive expression vector pGAPZ $\alpha$ A-Pre-Onc-DV3 was digested with $B g l \mathrm{II}$ and $E c o$ RI. Lane 1, the 1-kb DNA ladder marker; lane 2, digested fragments.

to replace the onconase. RNA degradation was assessed by agarose gel electrophoresis.

Determination of enzymatic parameters of the expression products using the double reciprocal. With $1 \mathrm{mg} / \mathrm{ml}$ solution of yeast transfer RNA (tRNA) as a substrate, various agents were successively added to assay the enzymatic activity of the purified Onc-DV3 by drawing a portrait of change values of $\mathrm{OD}_{260}$ along the RNase activity. The experiment was repeated at least three times.

Cell lines, culture, and the MTT assay. The paired highly metastatic and non-metastatic cell lines used were as follows: i) PC-3M-1E8, a human prostate cell line (highly metastatic), ii) PC-3M-2B4, a human prostate cell line, iii) MDA-MB-231, a human breast carcinoma cell line (highly metastatic), iv) MCF-7, a human breast carcinoma cell line, 

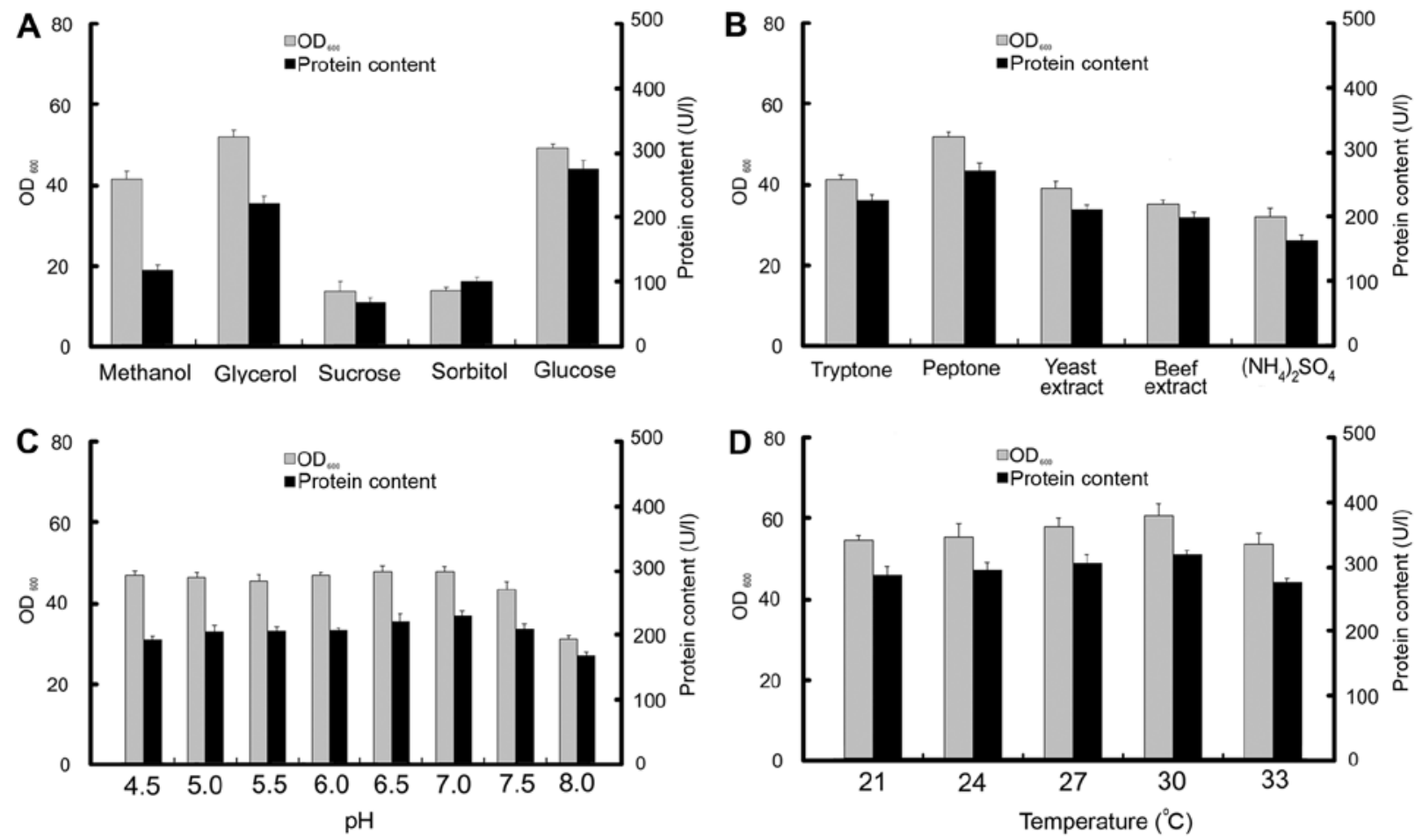

Figure 3. Effects of (A) different carbon sources, (B) nitrogen sources, (C) medium initial $\mathrm{pH}$ and (D) cultivation temperature on onconase-DV3 production in P. pastoris X 33. Data are presented as the means $\pm \mathrm{SD}$ of triplicate determinations.

v) PG-BE1, a human lung cancer cell line (highly metastatic), vi) PG-LH7, a human lung cancer cell line, vii) L-02, a human normal liver cell, and viii) HEK293, a human embryonic kidney cell line.

All of the cell lines were kept in our laboratory in RPMI-1640 medium (Invitrogen) with 20\% fetal bovine serum and $10 \%$ DMSO at $-80^{\circ} \mathrm{C}$. Cells were cultured in RPMI-1640 medium with $10 \%$ fetal bovine serum, $100 \mathrm{U} / \mathrm{ml}$ penicillin, and $100 \mu \mathrm{g} / \mathrm{ml}$ streptomycin at $37^{\circ} \mathrm{C}$ in $5 \% \mathrm{CO}_{2}$. The cells (PC-3M-1E8, PC-3M-2B4, MDA-MB-231, MCF-7, PG-BE1, PG-LH7, L-02, HEK293) were seeded on 96-well flat-bottomed plates at 3,000 cells/well, and incubated at $37^{\circ} \mathrm{C}$ in $5 \% \mathrm{CO}_{2}$ atmosphere for $24 \mathrm{~h}$. Then, the cells were treated with Onc-DV3 after removing the medium at serial dilutions $(0.05,0.10,0.20,0.40,0.80,1.60$, and $3.20 \mu \mathrm{M})$. There were six individual wells for each dose. The blank control was the dilution medium without added sample. The cells were incubated in 96 -well flat-bottomed plates at $37^{\circ} \mathrm{C}$ in $5 \% \mathrm{CO}_{2}$ atmosphere for $72 \mathrm{~h}$, after which the supernatant was removed, and the cells were washed with PBS ( $\mathrm{pH}$ 7.4). The cells were incubated in medium containing $20 \mu \mathrm{l}$ MTT solution $(5 \mathrm{mg} / \mathrm{ml})$ at $37^{\circ} \mathrm{C}$ for $4 \mathrm{~h}$. In order to dissolve the formed formazan crystals, $100 \mu$ l dimethyl sulfoxide (DMSO) was added after removing the supernatant. The OD was measured using the ELISA microplate reader at $490 \mathrm{~nm}$. Cytotoxicity to the cancer cells was determined by survival rate (\%). The experiment was repeated at least three times. Data are presented as mean $\pm \mathrm{SD}$.

\section{Results}

Construction of an expression vector. A synthesized 560 bp Pre-Onc-DV3 gene was inserted into the pGAPzaA vector under control of the GAP promoter, by integrating the coding gene in frame with the $S$. cerevisiae $\alpha$-factor pre-secretion signal sequence. The constitutive expression of pGAPz $\alpha$-Pre-Onc-DV3 is shown (Fig. 1). The extracted recombinant plasmid was identified by digesting with $B g l$ II and EcoRI, producing a DNA fragment $\sim 1,050$ bp (Fig. 2). To confirm validity of the open reading frame, the full-length promoter and Pre-Onc-DV3 was sequenced (data not shown). Zeocin was used to screen the E. coli TOP10 transformants.

Screening of constitutive Pichia X33 clones of recombinant $p G A P$. The reconstructed vector was extracted and digested with $B \ln \mathrm{I}$ to obtain a linear recombinant vector. Then, the linear vector of pGAPZ $\alpha$ A-Pre-Onc-DV3 was employed to transform P. pastoris X33 by electroporation. The X33 transformants harboring the recombinant vector were screened depending on their resistance to Zeocin on YPD plates containing different concentrations of Zeocin. The 21 transformants were selected on YPD plates containing $400 \mu \mathrm{g} / \mathrm{ml}$ Zeocin, and were confirmed by genomic DNA PCR analysis. The expression ability of these transformants was determined by measuring the medium supernatant for RNA degradation efficiency.

Effects of carbon source, temperature, and $\mathrm{pH}$ on the production of onconase-DV3 immunotoxin. The effects of a few carbon sources on the production of Onc-DV3 immunotoxin during the fermentation process were evaluated. The X33 transformant with the highest expression level of recombinant immunotoxin was selected as an initial seed and cultured in modified YPD in which the glucose was $2 \%(w / v)$, but was replaced with different carbon sources (glucose, sorbitol, 


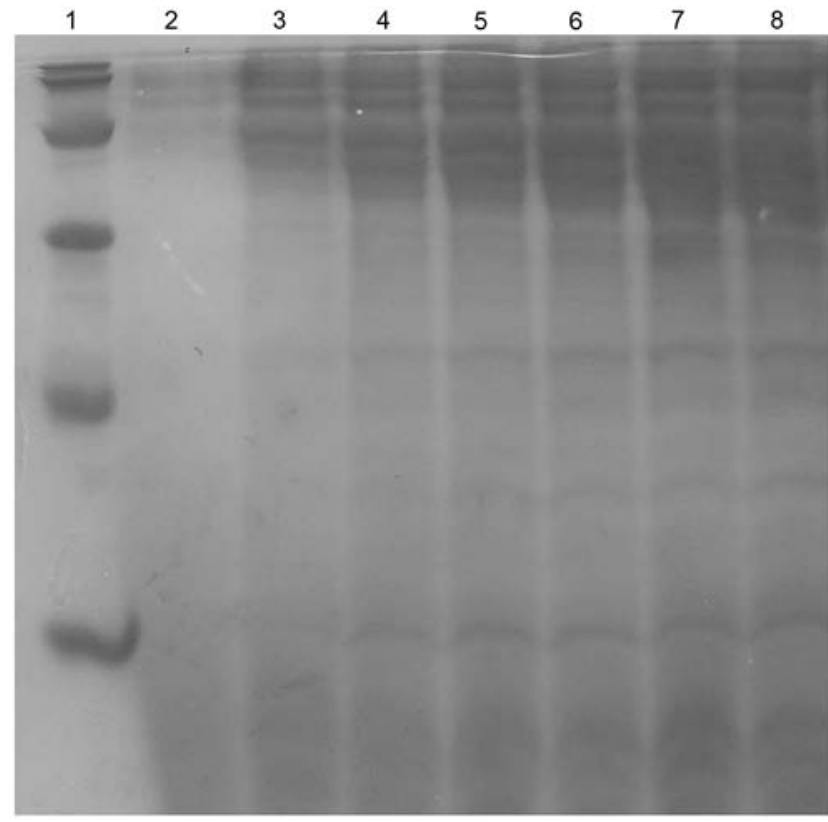

Figure 4. SDS-PAGE analysis of time-course expression of onconase-DV3 immunotoxin in the medium supernatant. Lane 1, marker; lanes 2-8, the medium supernatants at various time-points $(15,25,35,45,55,65,75 \mathrm{~h})$ after inoculation.

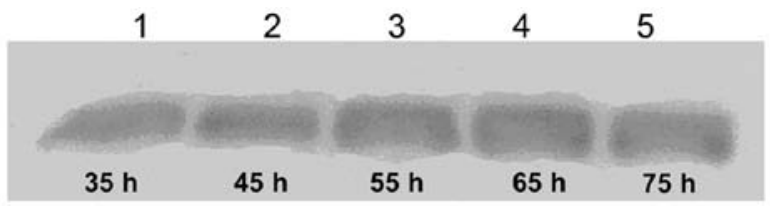

Figure 5. Western blot results of the expression of onconase-DV3 by the recombinant $P$. pastoris X33. Lanes 1-5, the medium supernatants at various time-points $(35,45,55,65,75 \mathrm{~h})$.

sucrose, methanol, or glycerol). The results demonstrated that glucose was the most favorable carbon source, with a maximum expression level of immunotoxin of $\sim 310 \mathrm{U} / 1$ after $60 \mathrm{~h}$ of culture. The results are shown in Fig. 3A. Significantly, the biomass achieved the highest level when glycerol was used as a carbon source, and immunotoxin protein production was much lower than that of glucose as a carbon source. Compared to glucose and glycerol, both the biomass and production level of Onc-DV3 immunotoxin were much lower when using methanol, sucrose, or sorbitol as the carbon source. The main nitrogen sources were evaluated for their capacity to produce Onc-DV3 immunotoxin [tryptone, peptone, yeast extract, beef extract, $\left.\left(\mathrm{NH}_{4}\right)_{2} \mathrm{SO}_{4}\right]$. The results demonstrated that peptone was the most favorable nitrogen source. The maximum expression level of immunotoxin was $\sim 310 \mathrm{U} / 1$ after $60 \mathrm{~h}$ of culture (Fig. 3B). The cells were grown in YPD medium (pH 7.0) at $21,24,27,30$, and $33^{\circ} \mathrm{C}$ to evaluate the effects of temperature on biomass and Onc-DV3 immunotoxin production (Fig. 3D). The biomass and production of Onc-DV3 did not show remarkable variance under different temperatures. The selected temperature for Onc-DV3 expression was at $30^{\circ} \mathrm{C}$ during fermentation, according to the empirical of higher enzyme activity at higher culture temperature (8). The effects of different medium initial $\mathrm{pH}(4.5,5.0,5.5,6.0,6.5,7.0,7.5$, $8.0)$ at $30^{\circ} \mathrm{C}$ on biomass and Onc-DV3 production were also checked during culture. The results showed (Fig. 3C) that the initial $\mathrm{pH}$ of the YPD medium had little effect on the biomass, but Onc-DV3 expression level was highest at $\mathrm{pH}$ 7.0.

The expression levels of recombinant immunotoxin at different times during the culture were analyzed by western blot analysis using anti-onconase polyclonal antibody. The results are shown in Figs. 4 and 5. The production of the recombinant immunotoxin was presented at $35 \mathrm{~h}$ and reached the highest production at $65 \mathrm{~h}$ in a flask culture.

Fed-batch fermentation. By using optimized conditions, a 50-1 fermentor was applied to evaluate the ability for large-scale constitutive expression of Onc-DV3 immunotoxin using GAP promoter in $P$. pastoris, with the above selected method. The time-course for biomass and production of Onc-DV3 in the 50-1 fermentor are shown in Fig. 6. The production value of the recombinant immunotoxin increased with the biomass until $72 \mathrm{~h}$. The biomass $\left(\mathrm{OD}_{600}\right)$ was elevated to $\sim 300$ during fed-batch fermentation in a 50-1 fermentor. The production of Onc-DV3 in the 501 fermentor reached about $2 \times 10^{3} \mathrm{U} / 1$ after $72 \mathrm{~h}$ of fermentation compared with that in the shake flask culture of $3.1 \times 10^{2} \mathrm{U} / 1$. The results revealed that the constitutive expression of the Onc-DV3 recombinant immunotoxin was

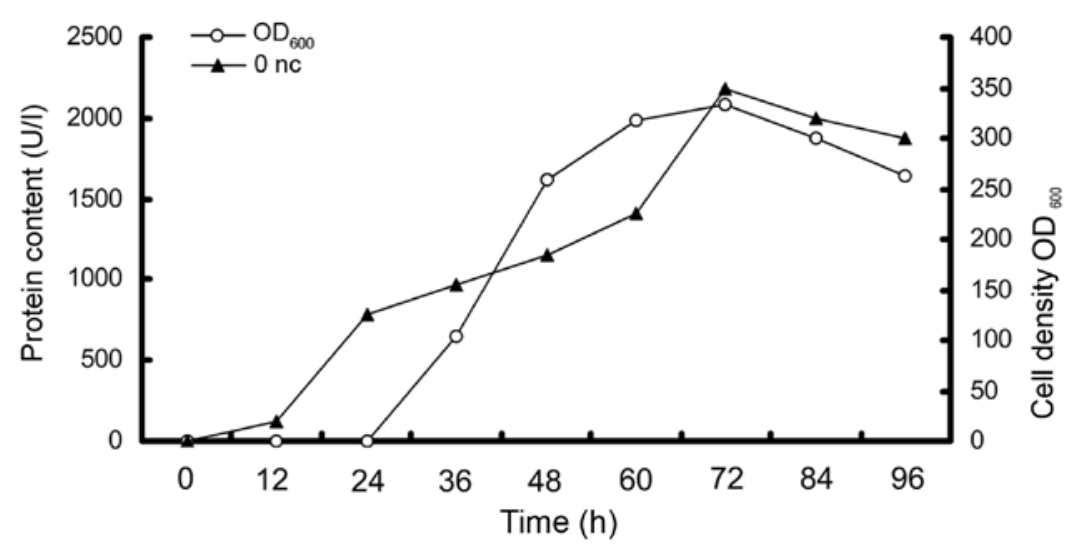

Figure 6. Cell growth, protein concentration, RNase activity of onconase-DV3 in the 50-1 fermentor with modified complex medium. Curves for cell growth $\left(\mathrm{OD}_{600}\right)$ and RNase activity during the fermentation process. 
Table I. A summary of the purification process for the fusion protein onconase-DV3 produced by $P$. pastoris.

\begin{tabular}{lcccc}
\hline $\begin{array}{l}\text { Purification } \\
\text { step }\end{array}$ & $\begin{array}{c}\text { Volume } \\
\text { (liters) }\end{array}$ & $\begin{array}{c}\text { Onconase-DV3 } \\
\text { (U/l) }\end{array}$ & $\begin{array}{c}\text { Purity } \\
(\%)\end{array}$ & $\begin{array}{c}\text { Cumulative } \\
\text { yield (\%) }\end{array}$ \\
\hline $\begin{array}{lcccc}\text { Culture } \\
\text { supernatant }\end{array}$ & 35 & 2,045 & - & 100.0 \\
Ultrafiltration & 5 & 12,497 & - & 87.3 \\
SP Sepharose & 3 & 13,026 & 71.2 & 54.6 \\
Sephadex G75 & 5 & 3,836 & 96.1 & 26.8 \\
\hline
\end{tabular}

less hazardous to $P$. pastoris. It is viable to efficiently produce Onc-DV3 recombinant immunotoxin in the 501 fermentor by adopting the constitutive fermentation strategy established in this study.

Purification and characterization of onconase-DV3 recombinant immunotoxin. The recombinant immunotoxin was isolated from the medium supernatant after ultrafiltration using membranes of 60 and $10 \mathrm{kDa}$ and purified by SP Sepharose ion exchange chromatography and Sephadex G-75 gel chromatography. The purity of the recombinant immunotoxin reached $97.0 \%$ with the recovery level of $12.8 \%$ (Table I). The purified immunotoxin showed a single band on SDS-PAGE at $20.0 \mathrm{kDa}$ (Fig. 7), which was near the theoretical value for this recombinant protein.

The biological activity assay of Onc-DV3 was carried out by agrose electrophoresis and increment ultraviolet absorption (Fig. 8). RNA hydrolytic activity of the biological activity of Onc-DV3 was analyzed according to RNase assay from the onconase domain of Onc-DV3 (Table II). The results confirmed that the recombinant immunotoxin Onc-DV3 produced by the GAP promoter-derived expression system maintained high biological activity.

In conclusion, Onc-DV3 recombinant immunotoxin was expressed under the control of the GAP promoter in the $P$. pastoris expression system with high production and high biological activity.

MTT assay. Every strain of the tumor cells was cultured and treated with immunotoxin Onc-DV3 and incubated for $72 \mathrm{~h}$. The survival rate of the cells as indicated by $\mathrm{OD}_{490}$ is shown in Table III. The trials of Onc-DV3 with tumor cells showed high efficient inhibition in highly metastatic tumor cells (PC-3M-1E8, PG-BE1, MDA-MB-231; the survival rate varied from $24.79 \pm 7.31$ to $27.61 \pm 9.16$ ), middle efficiency on poorly metastatic tumor cells (PC-3M-2B4, MCF-7, PG-LH7, the survival rate varied from $53.38 \pm 17.37$ to $59.64 \pm 8.03$ ), and no effect on normal cells (L-02, HEK293).

\section{Discussion}

The metastasis of tumor cells is the main cause of cancer-related death due to the rapid proliferation, the poor differentiation and the limited clinical efficacy of traditional treatments on tumor metastasis. Targeted cancer therapies based on immunological

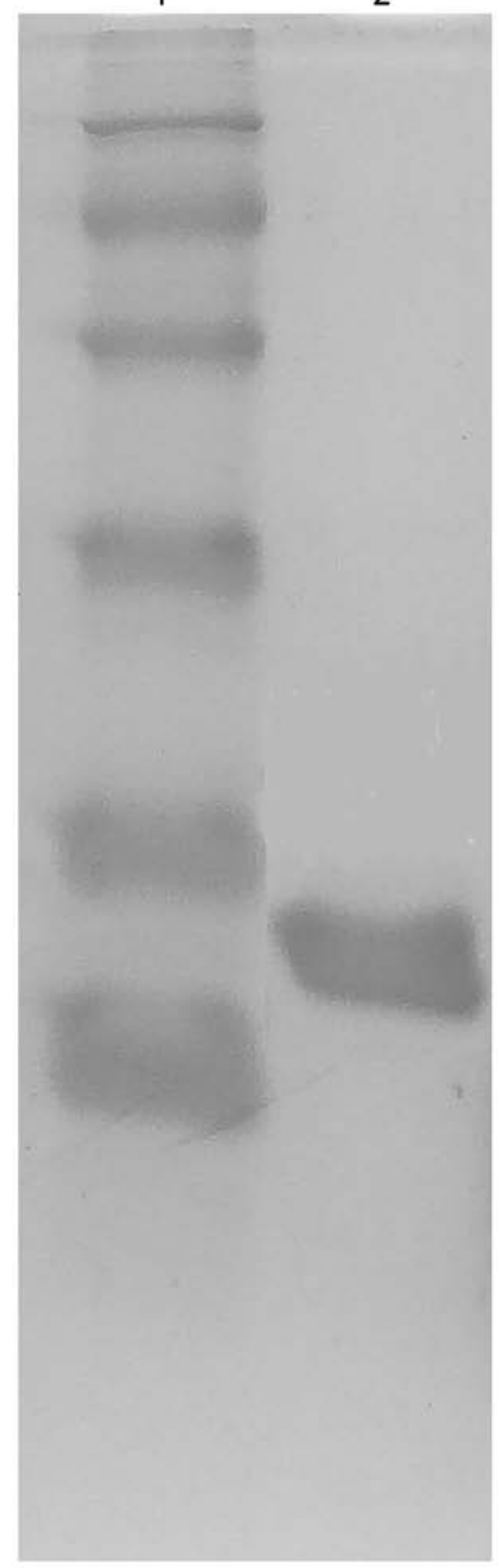

Figure 7. SDS-PAGE analysis of purified onconase-DV3 immunotoxin. Lane 1, markers; lane 2, purified onconase-DV3 immunotoxin.

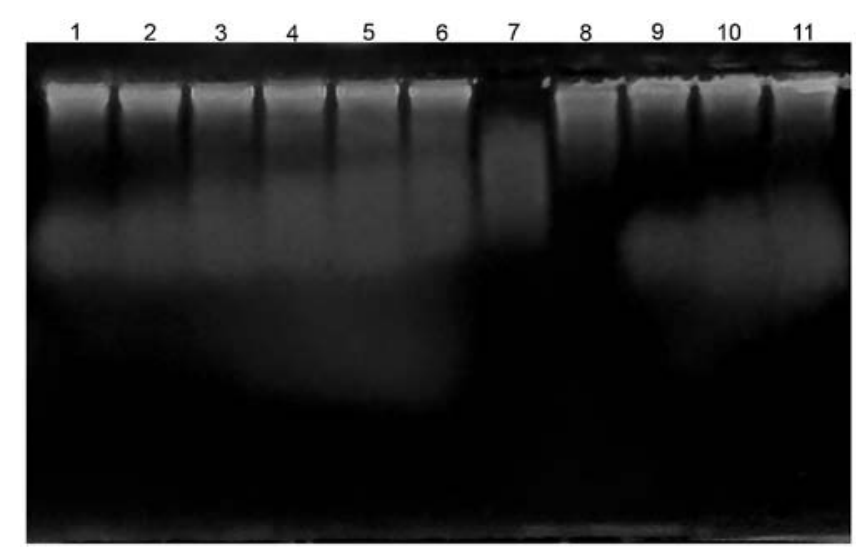

Figure 8. RNase activity of Onc-DV3. The activities of Onc-DV3 for different concentrations were compared with RNase A on agarose electrophoresis. 
Table II. Determination of RNase activity of the immunotoxin product.

\begin{tabular}{lccccccccc}
\hline Number & 1 & 2 & 3 & 4 & 5 & 6 & Sample & Sample & Sample \\
\hline Tris-HCl buffer $(\mu 1)$ & 850 & 850 & 850 & 850 & 850 & 850 & 850 & 850 & 850 \\
tRNA solution $(\mu \mathrm{l})$ & 100 & 100 & 100 & 100 & 100 & 100 & 100 & 100 & 100 \\
Time (min) & 30 & 30 & 30 & 30 & 30 & 30 & 30 & 30 & 30 \\
$50 \mu 1$ Rnase A (U) & 10 & 8 & 6 & 4 & 2 & 0 & - & - & - \\
Onc-DV3 $(\mu 1)$ & - & - & - & - & - & - & 400 & 400 & 400 \\
Change of $\mathrm{OD}_{260}$ & 0.92 & 0.76 & 0.58 & 0.42 & 0.22 & 0 & 0.14 & 0.18 & 0.13 \\
\hline
\end{tabular}

Table III. The survival rate of cells treated with $0.4 \mu \mathrm{M}$ Onc-DV3.

\begin{tabular}{lcc}
\hline Cell line & Survival rate $(\%)^{\mathrm{a}}$ & $\begin{array}{c}\text { P-value } \\
\text { (vs. control group) }\end{array}$ \\
\hline PC-3M-1E8 & $24.79 \pm 7.31$ & 0.007 \\
PG-BE1 & $25.85 \pm 6.72$ & 0.005 \\
MDA-MB-231 & $27.61 \pm 9.16$ & 0.032 \\
PC-3M-2B4 & $53.38 \pm 17.37$ & 0.016 \\
MCF-7 & $55.19 \pm 10.85$ & 0.028 \\
PG-LH7 & $59.64 \pm 8.03$ & 0.019 \\
L-02 & $107.13 \pm 21.80$ & 0.041 \\
HEK293 & $125.79 \pm 19.32$ & 0.027 \\
\hline
\end{tabular}

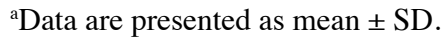

recognition of tumor cell-specific targets are expected to be more effective than traditional treatments and less harmful to normal cells.

The DV3 can selectively bind to metastatic tumors, but has no cytotoxicity to induce tumor cell apoptosis. Therefore, it needs to be linked with a molecule which is capable of causing tumor cell apoptosis.

Onconase has demonstrated its antitumor activity on several types of tumors and has been developed as a drug for malignant pleural mesothelioma (MPM).

A bivalent targeted domain has been reported to be more effective than using a single targeted domain for targeting against the receptor. The dimer DV3 markedly improved the tumor cell killing activity than the single one. Since multicopy seems to cause highly effective internalization (29-33), $(\mathrm{DV} 3)_{2}$ with onconase may provide a more efficient approach for delivering RNase payloads into the cytosol of metastatic tumor cells.

The main systemic toxicity of onconase is the damage of proximal kidney tubular cells in which onconase exhibits highly non-specific uptake by tissues $(34,35)$. The linkage of onconase and (DV3) $)_{2}$ is crucial so that it can specifically target metastatic tumor tissue.

In the present study, two copies of DV3 were selected to be linked to onconase to prepare an antitumor drug for metastatic tumors.

The best method of preparation was to construct the fusion gene of (DV3 $)_{2}$ and onconase, but formation of the cyclization of the glutamine residue (Gln) in the N-terminal contained by onconase may be difficult to be expressed in P. pastoris. Guided by the $\alpha$-mating factor, high bioactivity and production were obtained.

Since it was not clear whether the carbon source, the nitrogen source, the temperature, or $\mathrm{pH}$ affect the expression level during the fermentation of Onc-(DV3) $)_{2}$, in order to ensure a high level of expression of Onc-DV3, these parameters were evaluated.

We demonstrated that the combination of onconase to a bivalent DV3 caused selective and specific cytotoxicity only towards metastatic tumor cells whereas onconase alone mediated cytotoxicity towards both metastatic and non-metastatic tumor cells.

The results of the cytotoxicity experiments of the DV3 + onconase mixture, onconase-single DV3, and onconase-double DV3 revealed a progressive antitumor effect, suggesting that double DV3 could deliver more target Onc to metastatic tumor cells and selectively enhance the cytotoxicity of onconase.

According to its specific and selective antitumor efficacy on metastatic tumor cells, we expect that further studies of Onc-DV3 could act in its development as a clinical drug.

\section{Acknowledgements}

This study was supported by Jilin Province Science and Technology Key Problem of China (20140203014YY).

\section{References}

1. Darzynkiewicz Z, Carter SP, Mikulski SM, Ardelt WJ and Shogen K: Cytostatic and cytotoxic effects of Pannon (P-30 protein), a novel anticancer agent. Cell Tissue Kinet 21: 169-182, 1988.

2. Mosimann SC, Ardelt W and James MN: Refined 1.7 A X-ray crystallographic structure of P-30 protein, an amphibian ribonuclease with anti-tumor activity. J Mol Biol 236: 1141-1153, 1994.

3. Ardelt W, Mikulski SM and Shogen K: Amino acid sequence of an anti-tumor protein from Rana pipiens oocytes and early embryos. Homology to pancreatic ribonucleases. J Biol Chem 266: 245-251, 1991.

4. Gorbatyuk VY, Tsai CK, Chang CF and Huang TH: Effect of N-terminal and Met23 mutations on the structure and dynamics of onconase. J Biol Chem 279: 5772-5780, 2004.

5. Bretscher LE, Abel RL and Raines RT: A ribonuclease A variant with low catalytic activity but high cytotoxicity. J Biol Chem 275: 9893-9896, 2000.

6. Wu Y, Mikulski SM, Ardelt W, Rybak SM and Youle RJ: A cytotoxic ribonuclease. Study of the mechanism of onconase cytotoxicity. J Biol Chem 268: 10686-10693, 1993. 
7. Saxena SK, Sirdeshmukh R, Ardelt W, Mikulski SM, Shogen K and Youle RJ: Entry into cells and selective degradation of tRNAs by a cytotoxic member of the RNase A family. J Biol Chem 277: 15142-15146, 2002.

8. Suhasini AN and Sirdeshmukh R: Transfer RNA cleavages by onconase reveal unusual cleavage sites. J Biol Chem 281: 12201-12209, 2006.

9. Rodríguez M, Torrent G, Bosch M, Rayne F, Dubremetz JF, Ribó M, Benito A, Vilanova M and Beaumelle B: Intracellular pathway of onconase that enables its delivery to the cytosol. J Cell Sci 120: 1405-1411, 2007.

10. Newton DL, Hansen HJ, Mikulski SM, Goldenberg DM and Rybak SM: Potent and specific antitumor effects of an anti-CD22-targeted cytotoxic ribonuclease: Potential for the treatment of non-Hodgkin lymphoma. Blood 97: 528-535, 2001.

11. Pavlakis N and Vogelzang NJ: Ranpirnase - an antitumour ribonuclease: Its potential role in malignant mesothelioma. Expert Opin Biol Ther 6: 391-399, 2006.

12. Lee I, Kalota A, Gewirtz AM and Shogen K: Antitumor efficacy of the cytotoxic RNase, ranpirnase, on A549 human lung cancer xenografts of nude mice. Anticancer Res 27: 299-307, 2007.

13. Chang CH, Gupta P, Michel R, Loo M, Wang Y, Cardillo TM and Goldenberg DM: Ranpirnase (frog RNase) targeted with a humanized, internalizing, anti-Trop-2 antibody has potent cytotoxicity against diverse epithelial cancer cells. Mol Cancer Ther 9: 2276-2286, 2010.

14. Hu XF and Xing PX: Discovery and validation of new molecular targets for ovarian cancer. Curr Opin Mol Ther 5: 625-630, 2003

15. Ménard S, Pupa SM, Campiglio M and Tagliabue E: Biologic and therapeutic role of HER2 in cancer. Oncogene 22: 6570-6578, 2003.

16. Balkwill F: The significance of cancer cell expression of the chemokine receptor CXCR4. Semin Cancer Biol 14: 171-179, 2004.

17. Snyder EL, Saenz CC, Denicourt C, Meade BR, Cui XS Kaplan IM and Dowdy SF: Enhanced targeting and killing of tumor cells expressing the CXC chemokine receptor 4 by transducible anticancer peptides. Cancer Res 65: 10646-10650, 2005.

18. Saar K, Lindgren M, Hansen M, Eiríksdóttir E, Jiang Y, Rosenthal-Aizman K, Sassian M and Langel U: Cell-penetrating peptides: A comparative membrane toxicity study. Anal Biochem 345: 55-65, 2005.

19. Lu S, Tager LA, Chitale S and Riley LW: A cell-penetrating peptide derived from mammalian cell uptake protein of Mycobacterium tuberculosis. Anal Biochem 353: 7-14, 2006.

20. Snyder EL and Dowdy SF: Cell penetrating peptides in drug delivery. Pharm Res 21: 389-393, 2004

21. Rhee M and Davis P: Mechanism of uptake of C105Y, a novel cell-penetrating peptide. J Biol Chem 281: 1233-1240, 2006.

22. Watkins CL, Brennan P, Fegan C, Takayama K, Nakase I, Futaki S and Jones AT: Cellular uptake, distribution and cytotoxicity of the hydrophobic cell penetrating peptide sequence PFVYLI linked to the proapoptotic domain peptide PAD. J Control Release 140: 237-244, 2009.
23. Park JW, Bang EK, Jeon EM and Kim BH: Complexation and conjugation approaches to evaluate siRNA delivery using cationic, hydrophobic and amphiphilic peptides. Org Biomol Chem 10: 96-102, 2012

24. 24. Macauley-Patrick S, Fazenda ML, McNeil B and Harvey LM: Heterologous protein production using the Pichia pastoris expression system. Yeast 22: 249-270, 2005.

25. Damasceno LM, Huang CJ and Batt CA: Protein secretion in Pichia pastoris and advances in protein production. Appl Microbiol Biotechnol 93: 31-39, 2012.

26. Sinha J, Plantz BA, Inan M and Meagher MM: Causes of proteolytic degradation of secreted recombinant proteins produced in methylotrophic yeast Pichia pastoris: Case study with recombinant ovine interferon-tau. Biotechnol Bioeng 89: 102-112, 2005.

27. Vassileva A, Chugh DA, Swaminathan S and Khanna N: Expression of hepatitis B surface antigen in the methylotrophic yeast Pichia pastoris using the GAP promoter. J Biotechnol 88: 21-35, 2001

28. Wang X, Sun Y, Ke F, Zhao H, Liu T, Xu L, Liu Y and Yan Y: Constitutive expression of Yarrowia lipolytica lipase LIP2 in Pichia pastoris using GAP as promoter. Appl Biochem Biotechnol 166: 1355-1367, 2012.

29. Pedersen MW, Jacobsen HJ, Koefoed K, Hey A, Pyke C, Haurum JS and Kragh M: Sym004: A novel synergistic anti-epidermal growth factor receptor antibody mixture with superior anticancer efficacy. Cancer Res 70: 588-597, 2010.

30. Wang Q, Villeneuve $\mathrm{G}$ and Wang Z: Control of epidermal growth factor receptor endocytosis by receptor dimerization, rather than receptor kinase activation. EMBO Rep 6: 942-948, 2005.

31. Fan Z, Lu Y, Wu X and Mendelsohn J: Antibody-induced epidermal growth factor receptor dimerization mediates inhibition of autocrine proliferation of A431 squamous carcinoma cells. J Biol Chem 269: 27595-27602, 1994.

32. Perez-Torres M, Guix M, Gonzalez A and Arteaga CL: Epidermal growth factor receptor (EGFR) antibody down-regulates mutant receptors and inhibits tumors expressing EGFR mutations. J Biol Chem 281: 40183-40192, 2006.

33. Vasandani VM, Burris JA and Sung C: Reversible nephrotoxicity of onconase and effect of lysine $\mathrm{pH}$ on renal onconase uptake. Cancer Chemother Pharmacol 44: 164-169, 1999.

34. Mikulski S, Grossman A, Carter P, Shogen K and Costanzi J: Phase-I human clinical-trial of onconase(r) (p-30 protein) administered intravenously on a weekly schedule in cancer-patients with solid tumors. Int J Oncol 3: 57-64, 1993.

35. Vasandani VM, Wu YN, Mikulski SM, Youle RJ and Sung C: Molecular determinants in the plasma clearance and tissue distribution of ribonucleases of the ribonuclease A superfamily. Cancer Res 56: 4180-4186, 1996. 